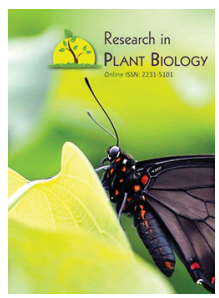

ISSN: $2231-5101$

\title{
Establishment of callus and cell suspension cultures of Helicteres isora $\mathrm{L}$.
}

\author{
Samrin Shaikh', Varsha Shriram², Tushar Khare' and Vinay Kumar ${ }^{1 *}$ \\ ${ }^{1}$ Department of Biotechnology, Modern College of Arts, Science and Commerce (Savitribai Phule Pune University), \\ Ganeshkhind, Pune 411016, India, ' Department of Botany, Prof. Ramkrishna More College, (Savitribai Phule Pune \\ University), Akurdi, Pune 411044, India
}

\begin{abstract}
Helicteres isora L. (Malvaceae) is a medicinal plant highly used in traditional therapeutic practices. It has shown wide-spectrum therapeutic activities including anti-plasmodial, hypoglycemic, hypolipidemic, hepatoprotective, antinociceptive, antioxidant and anti-HIV. Present investigation was undertaken with an objective of establishment of cell suspension cultures of this plant which can be further used for in vitro production of desired secondary metabolites and their further scale-up. Seed dormancy was broken using sulfuric acid and seedlings were raised in vitro. MS medium supplemented with 2,4-D $(0.5 \mathrm{mg} / \mathrm{L})$ produced maximum callus from the nodal explants. The callus produced was used as an explant for the establishment of suspension cultures. MS medium without any supplement was proved best for the establishment of cell suspension cultures of H. isora. To the best of our knowledge, this is the first report on H. isora cell suspension culture establishment.
\end{abstract}

*Corresponding Author: Vinay Kumar

Email: : vinay.kumar@

moderncollegegk.org

KEYWORDS: Helicteres isora, cell suspension cultures, medicinal plant, plant growth regulators, auxins, 2,-4-D

\section{INTRODUCTION}

Helicteres isora L. (Malvaceae) is a traditional medicinal plant, commonly referred as Indian Screw Plant. It is a deciduous shrub which can be spotted throughout the central and western India. As per the Ayurvedic medicinal system, almost all the parts of this plant are applicable in treatment of various conditions such as cough, asthma, diarrhea, urinary astringent, colic as well as snake bite etc. [1]. The pods of this shrub have demonstrated many valuable activities including anti-plasmodial activity [2], hypoglycemic activity, hepatoprotective activity [3], antihyperglycemic and hypo-lipidemic activities [4,5], antinociceptive activity [3], antioxidant potencies [6], antimicrobial resistance reversal activities [7] and anti-HIV activity [8]. This plant is also being reported to be applicable in type II diabetes treatment [9]. The phytochemical investigation of this plant have revealed wide range of medicinally important chemical entities such as phytosterols, isorin, cucurbitacin B, isocucurbitacin B, betulic acid, rosmarinic acid derivatives, daucosterol, lupeol, amyrin, fridelin, neolignans, taraxerone, diosgenin and volatile oil [5,9]. However, heavy rate of exploitation of this plant from the native wild conditions along with lower rate of natural seed germination and pollination inadequacy leads to the low obtainability of this plant. By considering the availability of rich phyto-constituents, there is an urgent necessity for germplasm conservation, optimization of the conditions for production of active biomolecules as well as further improvement and propagation of this plant. Owing to the medicinal and commercial importance of this plant, suspension cultures might prove the ideal method for propagation as well as phytochemical production [1].

Cell suspension cultures are defined as individual cells or group of cells growing in the liquid medium. The suspension culture denotes the homogenous population of the growing cells which are exposed to the available nutrients as whole cell surface is in contact with the liquid. Compared to the callus cultures on the solid medium, suspension cultures allow the recovery of higher quantities of cellular biomass, from which a substance of interest (secondary metabolites or enzymes) can be isolated in higher quantities as well [10]. Due to such advantageous culture conditions, elicitation of the secondary metabolites production is usually achieved in cell suspension cultures. Improved production of such secondary metabolites has been accomplished in many plants via suspension cultures. Some examples include production of Abietane diterpenoids in Cephalotaxus fortune suspension cultures [11], Gymnemic acid in Gymnema sylvestre suspension culture [12], Hypericin in Hypericum perforatum suspension culture [13], Jaceosidin in Saussurea medusa suspension culture [14], Resveratrol in Vitis vinifera suspension culture [15], Sanguinarine in Papaver somniferum suspension culture [16]. Though the callus culture from different explants as well as hairy root cultures have been reported by our group previously $[1,17]$ from $H$. isora, however,

Copyright: $\odot 2018$ The authors. This article is open access and licensed under the terms of the Creative Commons Attribution License (http://creativecommons.org/licenses/by/4.0/) which permits unrestricted, use, distribution and reproduction in any medium, or format for any purpose, even commercially provided the work is properly cited. Attribution — You must give appropriate credit, provide a link to the license, and indicate if changes were made. 
suspension cultures are not yet reported, and an attempt was made in this investigation to optimize the suspension culture establishment in this important medicinal plant. The intense commercial and medicinal significance of $H$. isora implies the necessity of the establishing of the cell suspension culture of this plant for biomass as well as secondary metabolite production. Hence we report herein the efficient procedure to attain healthy cell suspensions from callus of $H$. isora which can be explored for in vitro production and extraction of secondary metabolites.

\section{MATERIALS AND METHODS}

\section{Collection of Plant Material and In Vitro Seed Germination}

Mature pods (fruits) of $H$. isora were collected from wild conditions from Khopoli, Maharashtra, India. The samples were authenticated at Anantrao Pawar College, Pune and specimen voucher (No. APCP/21) was submitted. Seeds were separated from mature pods and used to raise the seedlings vie in vitro seed germination. Isolated seeds were allowed to react with concentrated sulfuric acid for 4 min to break the seed-dormancy. Excess acid was then removed aseptically by washing the treated seeds with sterile double distilled water for five times. Acid-treated seeds were then placed on solid MS Medium [18], containing sucrose $(3 \%)$, agar $(0.8 \%)$ at $\mathrm{pH} 5.8$ (autoclaved at $121^{\circ} \mathrm{C}, 15$ psi for $25 \mathrm{~min}$ ). Inoculated seed were then incubated for 3-4 days in dark, and transferred in white light condition after emergence of radical and plumule, at $25-27^{\circ} \mathrm{C}$. Cultures were continued for 3-4 week, and nodes excised from young shoots $(8-9 \mathrm{~cm})$ from in vitro raised seedlings served as the source for callus induction.

\section{Callus Induction}

Nodal explants (approximately $1 \mathrm{~cm}$ ) from 3-4 week old in vitroraised plantlets were used for callus induction. The effect of auxins and/or cytokinins (separately and/or in combination) was checked on induction of callus initiation and proliferation. Excised nodal explants were inoculated in the MS Medium containing Sucrose (3\%), Agar (0.8\%), fortified with plant growth regulators; either in single [auxins such as 2,4-D (0.5$\left.3 \mathrm{mg} \mathrm{L}^{-1}\right)$ and cytokinins such as BA $\left(0.5-3 \mathrm{mg} \mathrm{L}^{-1}\right)$ and Kin (0.5-3 $\left.\mathrm{mg} \mathrm{L}^{-1}\right)$ alone] or in combination [IAA + BA, IAA + $\mathrm{Kin}$, and $\mathrm{BA}+\mathrm{Kin}]$. Inoculated explants were maintained at $25-27^{\circ} \mathrm{C}$ with $16-\mathrm{h} / \mathrm{d}$ photoperiod. Subculturing was achieved on the fresh media of the same composition after each 20 days. Formation of the callus along with its biomass was recorded after 30 days on inoculation.

\section{Establishment of Cell Suspension Cultures}

Fresh and white calli obtained after 2 to 3 subcultures were used for the establishment of suspension cultures in MS medium without agar. Approximately $3.5 \mathrm{~g}$ of callus tissue was aseptically inoculated in the MS media $(50 \mathrm{~mL})$ with the composition as: Plain MS; MS + 2,4-D $0.5 \mathrm{mg} \mathrm{L}^{-1}(\mathrm{Hl})$; MS + 2,4-D $1 \mathrm{mg}$ $\mathrm{L}^{-1}(\mathrm{H} 2)$; and $\mathrm{MS}+2,4-\mathrm{D} 2 \mathrm{mg} \mathrm{L}^{-1}(\mathrm{H} 3)$. The cell suspension cultures were maintained on rotary shaker at 50-60 rpm (25$27^{\circ} \mathrm{C}, 16-\mathrm{h} / \mathrm{d}$ photoperiod). After 7-8 days in liquid culture, released/newly generated callus biomass was provided with fresh MS media of same composition. Healthy callus aggregates were repeatedly subcultured in new media for three cycles (total 21 days). After this period, biomass estimation was performed to compare the growth of callus in different media composition.

\section{Statistical Analyses}

All the experiments were performed in triplicates with at least 10 explants per treatment before conducting the statistical analyses. The results are presented as mean \pm standard error.

\section{RESULT AND DISCUSSION}

The acid treatment positively resulted into breaking of seed dormancy which provided increased germination rate of the seeds, as reported by our group previously [1]. The calculated germination percentage was $45.33 \%$. Inoculated nodal explants from 3-4 week old plantlets showed callus induction in all the PGR treatments (singly or in combination) (Table 1). However, maximum callus induction was observable in MS media fortified with 2,4-D singly, with $100 \%$ callus induction was achieved at the concentrations 0.5 and $1 \mathrm{mg} \mathrm{L}^{-1}$ of 2,4-D. At the same time, maximum biomass production was checked which revealed that $0.5 \mathrm{mg} \mathrm{L}^{-1}$ of 2,4-D was responsible for highest biomass production. A total of $0.82 \mathrm{~g}$ fresh weight per explant was recorded after 30 days of inoculation on solid MS media fortified with $0.5 \mathrm{mg} \mathrm{L}^{-1}$ of 2,4-D (Fig. 1). As proved to be the highest biomass producer, the callus generated at this concentration was further carried for establishing the suspension culture. 2,4-D has been reported previously responsible for callus induction and proliferation in various medicinal plants, six different species of Ocimum [19], Carthamus tinctorius [20] as well as in crop plants including Oryza sativa [21], Saccharum spp. [22], and Miscanthus lutarioriparius [23]. All these reports indicated importance of 2,4-D for callus induction and proliferation as in the present report.

The callus obtained at the previous step showed disaggregation of cell mass after approximately 5-7 days of inoculation in liquid MS medium. The disaggregated calli were then showed

Table 1: Effect of plant growth regulators (PGRs) on production of callus from nodal explants of Helicteres isora $\mathrm{L}$

\begin{tabular}{lcccc}
\hline MS+PGR s & $\mathrm{mg} / \mathrm{L}$ & Callus induction $\%$ & $\mathrm{FW}(\mathrm{g})$ & $\mathrm{DW}(\mathrm{g})$ \\
\hline Control & -- & -- & -- & -- \\
$2,4-\mathrm{D}$ & 0.5 & $100 \pm 1.5$ & $0.82 \pm 0.04$ & $0.05 \pm 0.009$ \\
& 1.0 & $71.4 \pm 1.9$ & $0.37 \pm 0.03$ & $0.03 \pm 0.008$ \\
& 2.0 & $100 \pm 2.1$ & $0.54 \pm 0.04$ & $0.04 \pm 0.008$ \\
& 3.0 & $92.8 \pm 1.8$ & $0.67 \pm 0.11$ & $0.04 \pm 0.007$ \\
BAP & 0.5 & $21.4 \pm 0.8$ & $0.10 \pm 0.01$ & $0.01 \pm 0.003$ \\
& 1.0 & $42.8 \pm 1.4$ & $0.40 \pm 0.02$ & $0.04 \pm 0.002$ \\
& 2.0 & $71.4 \pm 1.9$ & $0.31 \pm 0.04$ & $0.03 \pm 0.002$ \\
& 3.0 & $28.6 \pm 2.6$ & $0.07 \pm 0.01$ & $0.01 \pm 0.004$ \\
Kin & 0.5 & $64.3 \pm 1.8$ & $0.08 \pm 0.01$ & $0.01 \pm 0.003$ \\
& 1.0 & $85.7 \pm 3.1$ & $0.63 \pm 0.12$ & $0.06 \pm 0.002$ \\
& 2.0 & $64.3 \pm 2.9$ & $1.34 \pm 0.14$ & $0.14 \pm 0.009$ \\
& 3.0 & $64.3 \pm 1.8$ & $0.77 \pm 0.09$ & $0.08 \pm 0.006$ \\
\hline
\end{tabular}

Res Plant Biol • 2018 • Vol 8 

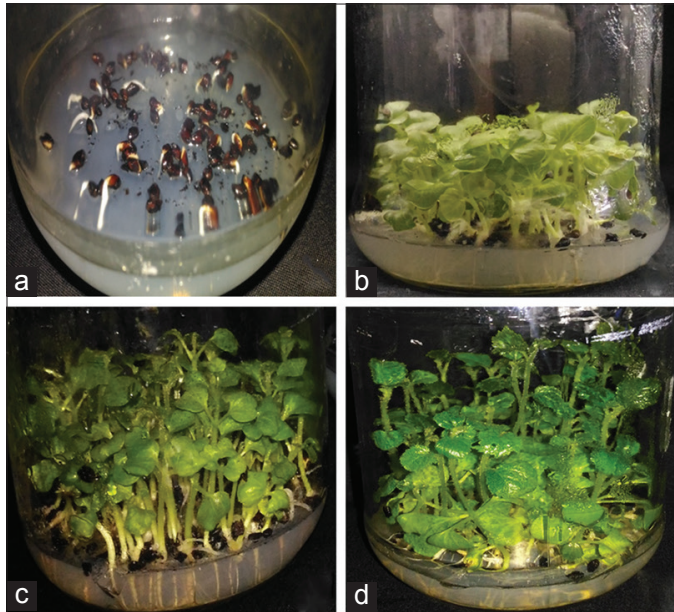

Figure 1: In vitro seed germination of Helicteres isora L. (A) Acidtreated germinating seeds after 4 days of inoculation; germinated seedling after (B) 12 days (C) 20 days (D) 25 days
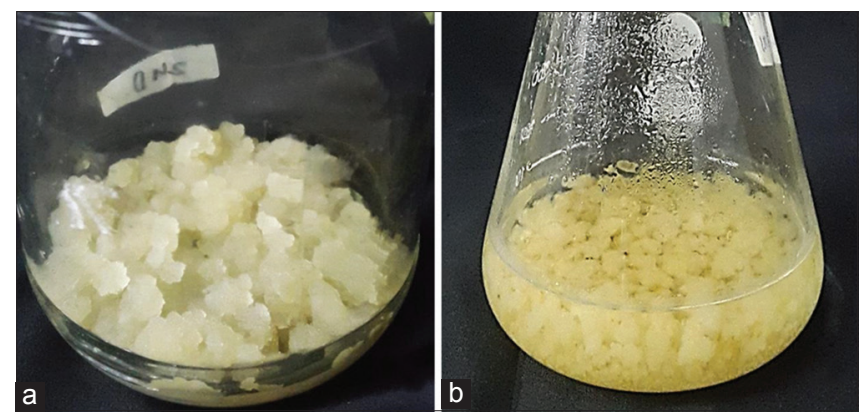

Figure 2: (A) Callus proliferation on $M S+2,4-D\left(0.5 \mathrm{mg} \mathrm{L}^{-1}\right)$ after 30 days of subculture (B) Suspension culture of Helicteres isora in MS medium after 30 days of inoculation

Table 2: Effect of varying concentrations of 2,4-D on production of cell suspension cultures of Helicteres isora L. Samples were harvested after 21 days (3 cycles of 7 days each) for recording FW and DW

\begin{tabular}{lccc}
\hline $\begin{array}{l}2,4-\mathrm{D} \\
(\mathrm{mg} / \mathrm{L})\end{array}$ & $\begin{array}{c}\text { Callus } \\
\text { inoculated }(\mathrm{g})\end{array}$ & $\begin{array}{c}\text { FW of Suspension } \\
\text { cultures }(\mathrm{g})\end{array}$ & $\begin{array}{c}\text { DW of Suspension } \\
\text { cultures }(\mathrm{g})\end{array}$ \\
\hline 0.0 & 3.5 & $17.75 \pm 1.7$ & $0.96 \pm 0.09$ \\
0.5 & 3.5 & $17.43 \pm 1.6$ & $0.82 \pm 0.07$ \\
1.0 & 3.5 & $10.78 \pm 1.2$ & $0.35 \pm 0.05$ \\
2.0 & 3.5 & $5.24 \pm 0.9$ & $0.31 \pm 0.05$ \\
\hline
\end{tabular}

increment in size with increase in the time. After 21 days of the inoculation, the total biomass analysis indicated that the suspension cultures growing in MS media without 2,4-D showed maximum biomass in terms of fresh as well as dry weight (Table 2). There was gradual decrease observed in the biomass produced with increase in the 2,4-D concentration $(0.5-2 \mathrm{mg}$ $\left.\mathrm{L}^{-1}\right)$. Hence it was noted that maximum biomass production was attained in plain MS medium after 21 days of inoculation (Fig. 2). There are several reports on establishment and use of suspension cultures for production of large-scale secondary metabolite production in a sustainable and eco-friendly way. Orihara and Ebizuka [24] established shake-flask cell suspension cultures of Olea europaea for the production of triterpene acids. Chattopadhyay et al. [25] scaled up the cell suspension cultures of Podophyllum to bioreactor level for the production of podophyllotoxins. The present holds merit since optimal cell suspension cultures were obtained on plain MS without using any PGR, which adds to the cost effectiveness of the method and may prove to be beneficial for production of desired secondary metabolites from the cell suspension cultures.

\section{ACKNOWLEDGMENTS}

The financial support for conducting this research work from Savitribai Phule Pune University, Pune in the form of Research Grant (No.: OSD/BCUD/392/132) is acknowledged.

\section{REFERENCES}

1. Shriram V, Kumar V, Shitole MG. Indirect organogenesis and plant regeneration in Helicteres isora L., an important medicinal plant. In Vitro Cell Dev Biol 2008; 44(3):186-93.

2. Pohocha N, Grampurohit ND. Anti-spasmodic activity of the fruits of Helicteres isora Linn. Phytother Res 2001; 15(1):49-52.

3. Kumar G, Murugesan AG, Pandian MR. Effect of Helicteres isora barks extract on blood glucose and hepatic enzymes in experimental diabetes. Pharmazie 2006; 61(4):353-355.

4. Chakrabarti R, Vikramadithyan RK, Mullangi R, Sharma VM, Jagadheshan H, Rao YN, Sairam P, Rajagopalan R. Antidiabetic and hypolipidemic activity of Helicteres isora in animal models. J Ethnopharmacol 2002; 81(3):343-349.

5. Venkatesh S, Reddy GD, Reddy YS, Sathyavathy D, Reddy BM. Effect of Helicteres isora root extracts on glucose tolerance in glucoseinduced hyper-glycemic rats. Fitoterapia 2004; 75 (3-4): 364-367.

6. Kumar V, Sharma M, Lemos M, Shriram V. Efficacy of Helicteres isora against free radicals, lipid peroxidation, protein oxidation and DNA damage. J Pharm Res 2013; 6(6): 620-625. doi: 10.1016/j. jopr.2013.05.017

7. Shriram V, Jahagirdar S, Latha C, Kumar V, Dhakephalkar P, Rojatkar S, Shitole MG. Antibacterial \& antiplasmid activities of Helicteres isora L. Indian J Med Res 2010; 132:94-99

8. Otake T, Mori H, Morimoto M, Ueba N, Sutardjo S, Kusomoto I, Hattori M, Namba T. Screening of Indonesian plant extracts for antihuman immuno deficiency virus type1 (HIV-1) activity. Phytother Res 1995; 9(1): 6-10

9. Kumar G, Banu GS, Murugesan AG, Rajasekara-Pandian M. Preliminary toxicity and phytochemical studies of aqueous bark extract of Helicteres isora L. Int J Pharm. 2007; 3:96-100.

10. Shahzad A, Parveen S, Sharma S, Shaheen A, Saeed T, Yadav V, Akhtar R, Ahmad Z, Upadhyay A. Plant Tissue Culture: Applications in Plant Improvement and Conservation. In Plant Biotechnology: Principles and Applications 2017 (pp. 37-72). Springer Singapore.

11. Xu X, Zhang W, Cao X, Xue S. Abietane diterpenoids synthesized by suspension-cultured cells of Cephalotaxus fortunei. Phytochem Lett 2011; 4:52-5.

12. Praveen N, Murthy HN, Chung IM. Improvement of growth and gymnemic acid production by altering the macro elements concentration and nitrogen source supply in cell suspension cultures of Gymnema sylvestre R. Br. Ind Crop Prod 2011; 33:282-6.

13. Walker TS, Pal Bais H, Vivanco JM. Jasmonic acid-induced hypericin production in cell suspension cultures of Hypericum perforatum L. (St. John's wort). Phytochemistry 2002; 60:289-93.

14. Zhao D, Fu C, Han Y, Lu D. Effects of elicitation on jaceosidin and hispidulin production in cell suspension cultures of Saussurea medusa. Process Biochem 2005; 40:739-45.

15. Yue $X$, Zhang $W$, Deng $M$. Hyper-production of ${ }^{13} \mathrm{C}$-labeled transresveratrol in Vitis vinifera suspension cell culture by elicitation and in situ adsorption. Biochem Eng J 2011; 53:292-6.

16. Holkova I, Bezakova L, Bilka F, et al. Involvement of lipoxygenase in elicitor-stimulated sanguinarine accumulation in Papaver somniferum suspension cultures. Plant Physiol Biochem 2010; 48, 887-92.

17. Kumar V, Desai D, Shriram. Hairy root induction in Helicteres isora and production of diosgenin in hairy roots. Nat Prod Bioprospect 2014; 4:107-112. doi: 10.1007/s13659-014-0011-9 
Shaikh, et al.

18. Murashige T, Skoog F. A revised medium for rapid growth and bioassays with tobacco tissue culture. Physiol Plant 1962; 15:473-479.

19. Sharma NK, Choudhary RC, Kumar M. Effects of 2, 4 dichlorophenoxy acetic acid $(2,4-D)$ on callus development of six Ocimum species. Medicinal Plants - Int J Phytomedicines Related Industries 2015; 7(1):35-40.

20. Kumari S, Pandey RK, Uttam K. In vitro callus induction from two different explants stem and leaf in Carthamus tinctorius Linn. Eur J Exp Bio 2015; 5(2):1-4.

21. Kumar V, Shriram V, Nikam TD, Kavi Kishor PB, Jawali N, Shitole MG. Assessment of tissue culture and antibiotic selection parameters useful for transformation of indica rice. Asian Australasian J Plant Sci Biotechnol 2008; 2(2):84-87.
22. Patel VS, Mehta R, Singh D, Patel D, Mali S, Naik K. Callus induction \& whole plant regeneration in sugarcane (Saccharum spp. complex) variety Co 86032. Green Farm 2015; 6(5):935-939.

23. Zhao L, Diao Y, Jin S, Zhou F, Hu Z. Effect of genotype and inflorescence develop-mental stage on callus induction and plant regeneration of Miscanthus /utarioripariu, a non-food biomass crop. Pak J Bot 2016; 48(2):717-722.

24. Orihara Y, Ebizuka Y, 2010. Production of Triterpene Acids by Cellsuspension Cultures of Olea europaea. In Olives and Olive Oil in Health and Disease Prevention (pp. 341-347).

25. Chattopadhyay S, Srivastava AK, Bhojwani SS, Bisaria VS. Production of podophyllotoxin by plant cell cultures of Podophyllum hexandrum in bioreactor. J Biosci Bioengineer 2002, 93(2):215-220. 